DOI: $10.1515 /$ ausfm-2018-0002

\title{
An Uncanny Cinema, a Cinema of the Uncanny. The Trope of the Doll in the Films of Manoel de Oliveira
}

\author{
Hajnal Király \\ Sapientia Hungarian University of Transylvania (Cluj-Napoca, Romania) \\ E-mail: hajnal.kiraly@gmail.com
}

\begin{abstract}
I argue that the trope of the doll, recurrent throughout the films of Manoel de Oliveira, is a visual figure that beyond narrative becomes a discourse on modernity and modernism, stillness and movement, life and death. Accordingly, I propose an overview of occurences of dolls and of "dollness" throughout the work of Oliveira - from Aniki Bobó (1942) to The Strange Case of Angelica (2010) - with the aim of tracking the line of transformations of an emblematic object into an aesthetic principle, a central figure involving psychoanalytical concepts such as the Freudian "uncanny," the fetish or the transitional object. ${ }^{1}$
\end{abstract}

Keywords: uncanny, doll, fetish, transitional object, modernity, modernism.

\section{Introduction: Defusing an Enigma}

Manoel de Oliveira is not only the longest lived film director of all times, active until his death, which occured at the very advanced age of 106, but also one of the most curious personalities of film history. Despite a scholarly interest in his films that used to participate regularly in prestigious European festivals, these were almost never shown in film theaters, therefore his work remains an "exquisite delicacy" for cinephiles. While praised by Serge Daney (2001), Jonathan Rosenbaum (1995) and David Bordwell (2013), just to name a few connaisseurs, most critics are puzzled when trying to discover a clue to his cinema, a task as difficult as finding out the secret of his advanced age. These preoccupations are at the origin of numerous interviews, portrait films and television reports (see, for example, Costa 1981; Baecque and Parsi 1999; Araújo 2014 and Costa Andrade

1 This work was supported by a grant of the Ministry of National Education, CNCS - UEFISCDI Romania, project number PN-III-P4-ID-PCE-2016-0418. 
2008), all keen to set up new categories, periods, concepts and comparisons for his somehow familiar, but still uncanny approach to cinema. The divide of the Salazar dictatorship, the tetralogy of "frustrated loves" (see Parsi 1981) - as Oliveira himself used to call the films with the same topic: Past and Present ( $O$ Passado e o Presente, 1972), Benilde, or the Virgin Mother (Benilde ou a Virgem Mãe, 1975), Doomed Love (Amor de Perdição, 1979) and Francisca (1981) -, the collaboration with Paulo Branco and Agustina Bessa-Luís, the preference for literary adaptations, cultural-historical topics and painterly allusions (especially to the Impressionism) are only a few, but persistent points of reference that help illuminate some aspects of his work, without providing, however, a coherent clue to interpretation. Similarly, based on the comparison of his style to different moments of film history, such as the German avantgarde (Labour on the Douro River [Douro, Faina Fluvial, 1931], Ruttmann's Berlin: a Symphony of a Great City [1927]), the Italian neo-realism (Aniki Bobó, 1942), the films of Robert Bresson and his model-theory, some films of Rohmer (his Marquise de $O$ [1976] and his moral tales), Buñuel (his predilection to parody, critique of bourgeoisie and thematization of fetishism), it can be stated that none of these similarities became constant in his work and these do not even provide a sufficient basis to call him a "modernist" filmmaker. The most complete non-Portuguese approach has been realized so far by Mathias Lavin, who in his book, La Parole et le lieu (2008) analyses one of the fundamental aspects of the Oliveirian cinema: the tensionate relationship between word and image, the gaps, delays and excesses that are responsible for the often disturbing effect on spectators. However, while setting up a coherent method for the analysis, this work doesn't fully illuminate the intertwining of an original philosophy of cinema with a life philosophy that comes to the fore in interviews. I argue that the visual excess characteristic of Oliveira's films is nothing else than a figuration of his constant preoccupation with the mystery of life and death, history and ultimately, time. His attraction to sinister, unusal, uncanny topics, reflected in many of his titles containing words like "doomed," "strange," "magic," "eccentric" is paired with a style that often seems familiar, just to be subverted, parodized or interrupted most unexpectedly. At the same time, the mannerism and aestheticization, the all-pervasive preference for the still(ed) image, painterly compositions and tableaux vivants, reflects on the constant intention of the Western man to hold back time and grab the instant, in accordance with Agamben's view on aesthetics as the destiny of contemporary art: "thus aesthetics is not simply the privileged dimension that progress in the sensibility of Western man has reserved for the work of art as his most proper 
place; it is, rather, the very destiny of art in the era in which, with tradition now severed, man is no longer able to find, between past and future, the space of the present, and gets lost in the linear time of history" $(1999,69)$.

All of Oliveira's work after his return to a very prolific filmmaking at the beginning of the 70s can be seen as an intention to save tradition, revive memories and fulfill unfinished projects from the Salazar era, when he was politically silenced. Unwilling (or unable) to recognize himself in the present (he is already in his sixties at the time of his return, an age at which other filmmakers retire), he chooses to bring the past to the present, arguably with the aim of making the present more familiar. This is the role of his many literary adaptations (most of them from Portuguese works and from the $19^{\text {th }}$ century) and a few films of Portuguese historico-cultural interest. What is striking about these films is the anachronism of their narratives, missing all connections to the present: young women dying of tuberculosis, people dying of grief and longing, moral stories about a decadent bourgeoisie, the self-destructive life of a $19^{\text {th }}$-century author, lives of historico-cultural personalities from the $19^{\text {th }}$ century, just to name a few topics. Similarly, settings and décors of the films are not revelatory of any specific moment of the $20^{\text {th }}$ century: the costumes, fashion items, cars and interiors represent a great heterogeneity of styles and periods, undermining, again, the actuality of the narrative and creating an uncanny effect. Under these circumstances, only one reality persists: that of the single image that becomes the sole present, or rather, a presence. Conflicted with a voice-over narrator or a voice-off reading of texts, characters' dialogues or monologues and text inserts, the carefully framed image often concentrates the meaning of the story emblematically, metonymically or metaphorically. This preference for the figural and figuration as alternative to narrativization is declared in what can be regarded a late ars poetica of Oliveira, The Old Man from Belém ( $O$ Velho do Restelo). In this short film launched in September 2014, three fundamental dimensions of Oliveira's work intertwine along a meditation on our suspended time: a cultural and civilizational allegory, a reflection on own cinema, and finally biographical, personal elements. The discussion between the four emblematic characters, seated side by side in an eternal garden, is like a diving in history, a seed fertilizing the memory of Oliveira. Camões, the author of the Luísiadas, Camilo Castelo Branco (19 ${ }^{\text {th }}$-century writer, author of the classical and very popular novel Doomed Love), Teixeira de Pascoaes, whose book on Camilo is evoked in this film, and Don Quixote are all emblematic cultural figures recurrent in Oliveira's films either as authors of adapted literary works (the case of Castelo Branco), or as models in terms of meditation on Portuguese history. 
With its historico-meditative tone, this allegorical episode inscribes itself in the line of a few films dealing with civilizational issues, mostly of Portuguese interest: No, or the Vain Glory to Command ('Non', ou A Vã Glória de Mandar, 1990), A Talking Picture (Um Filme Falado, 2003) and Cristopher Columbus - The Enigma (Cristóvão Columbo - O Enigma, 2007). A Talking Picture, considered by many critics a response to the $9 / 11$ attacks, is a road movie that follows a historian mother and her daughter on their journey from West to East, from Europe towards India, on boat, with stops at touristic sites emblematic of the encounter with the Muslim World. While Oliveira plays with the possibility of a globalized West where everyone understands each other despite speaking different languages (the guests on the board of the boat do so), his visionary premonition is pessimistic, even rootless: shortly after the cosmopolitan American captain (played by John Malkovich) gives the little girl a doll dressed in oriental costume, bombs are detected on board and the ship explodes before the girl and her mother (who return to fetch the doll from the cabin) could escape. The film closes with a freeze-frame of Malkovich's face, lit by the blast and revealing the horror of the Medusa-effect: turning still, as if petrified. The figurative role of the doll has been neglected so far by the critics (some refer to it as a "gift"); it is in fact an object, a product that emblematically and historically concentrates the economic and political aspects of West-Middle East relationships. As Agamben points out, the temporality of history is more present in a toy than in historical and archaeological monuments, to which Oliveira's road movie seems to be dedicated. "For in the toy, as in no other site, can we grasp the temporality of history in its pure differential and qualitative value. Not in a monument, an object of archaeological and scholarly research, which preserves in time its practical, documentary character (its 'material content,' Benjamin would have said); not in an antique, whose value is a function of its quantitative ageing; not in an archive document, which draws its value from its place in a chronology and a relationship of proximity and legality with the past event. The toy represents something more and something different from all these things. [...] What the toy preserves of its sacred or economic model, what survives of this after its dismemberment or miniaturization, is nothing other than the human temporality that was contained therein: its pure historical essence. The toy is a materialization of the historicity contained in objects, extracting it by means of a particular manipulation." (Agamben 1993a, 71.)

The toy, bought by the American captain in a bazaar, is emblematic of the historical, economic and civilizational exchange between the West and the Middle East, and it participates at the same time in the pessimistic, visionary allegory of 
these relationships in the $21^{\text {st }}$ century: the trip to Bombay, which throughout the film seemed to signify the hope of a cultural continuity and reconciliation, in the last scene turns into a nightmare. The death of the girl and her mother on a ship connecting the two civilizations translates as a gloomy vision of the future of the Portuguese nation in particular, and Europe in general, endangered by a crisis also involving the USA.

The toy, or more specifically, the doll, besides its role of "container" of meanings related to historicity and temporality, especially "the temporal dimension of a 'once upon a time' and a 'no more,"' as Agamben has shown it (1993a, 72), is a recurrent fetishistic object that can be considered one of the major clues to the Oliveirian work. As the "inexhaustible object of our desire and our fantasies" (Agamben 1993b, 58), it also represents the frustration of artistic creation: for Baudelaire, "the toy is the emblem of the relationship - of impenetrable joy mixed wilh stupefied frustration - that is the basis of artistic creation as of every relation between human and objects" (Agamben 1993b, 57).

Oliveira's aesthetics owes much to the myth of modernity, described by Baudelaire in his The Painter of Modern Life (1863): the artistic creation conceived as an adventure of the gaze turns everything into spectacle, just as fashion and makeup transforms women into dolls and mannequins, passive objects of the (male) gaze. Stillness, doll-ness, "to-be-looked-at-ness" or "imageness" of the female character, a heritage of the impressionist painting (especially Manet, whose paintings are often referred to in his films) is central to Oliveira's aesthetics of the frame, manifesting in a preference for window- and doorframes, mirrors. In what follows, I propose an overview of figurative occurences of dolls and of "dollness" throughout the work of Oliveira - from Aniki Bobó (1942) to The Strange Case of Angelica (O Estranho Caso de Angélica, 2010) - with the aim of tracking the line of transformations of an emblematic object into an aesthetic principle, a central figure involving a range of psychoanalytical concepts, such as the uncanny, the fetish or the transitional object.

\section{Aniki Bobó and the Doll in the Window}

Considered by many critics a proto-neorealist movie, the first feature film of Oliveira, Aniki Bobó tells a story spanning only a few days of working class children based in Porto, the home city of Oliveira. It is a tale played by non-professional children actors and reveals serious dramas that occur on the verge between play and reality, childhood and adulthood, life and death. The daily play of children takes place by 
the river Douro, between the river and the esplanade, a street with shops looking at the river, an in-between space representing childhood as a transiton between nature (represented by the enormous river) and culture/civilization, created and inhabited by adults. This transitional condition, the coming-of-age process is emphasized by the children's rhyme that the film's title derives from and which is chanted repeatedly by the protagonists: from the rhythm which evokes archaic rites, uncoherent words emerge denoting, in turn, animals, musical instruments, and biblical figures. The distance between adults and children is apparent from the very first scene of the film: the protagonist is playing with a bibelot (a miniature, a version of the toy) while his mother is preparing him for school, the bibelot breaks and he is slapped instantly by the mother. But this scene is only a premonition of the central topic that also involves conflicts with adults: a doll in a display window triggers a series of anecdotal scenes, by being stolen and finally delivered to the girl the child protagonist is desperately in love with. The image of the doll in the window is central for other reasons, too: it structures the narrative (on the one hand, it halts the action, the intense play of children, who always stop to admire it, on the other, it marks the turning points in the story) and it becomes an alternative to it, prefiguring the contemplative, visually charged, slow cinema of Oliveira. João Lopes was the first to point out the importance of the scene with the doll in the window in this film, reflecting on the uncanny effect triggered by the point of view of the doll (Lopes 1981). Indeed, the gaze of the children is paired with a counter shot that can only be that of the doll, a point of view shot coming from nowhere. [Figs. 1-2.] Two possible interpretations emerge, without mutually excluding each other: this is a projection of the children's belief in the magic of the toy that, just like in Playland from Pinocchio, can come to life. At the same time, it is a self-reflexive instant, where the object of the gaze reveals the spectator by staring back: this is again an effect established by the impressionist painting (of which Manet's Olympia, 1863, is paradigmatic), adopted later by cinema with the crash of the "fourth wall" that allowed characters to address the spectator. This effect will be widely used in Oliveira's films, especially in the ones in which he is opting for the frontal style, with characters reciting their lines while looking out at the spectator (e.g. Doomed Love, 1978 or The Day of Despair, 1992), but also in others where the act of looking and the woman as spectacle is thematized (Abraham's Valley/Vale Abraão, 1993), or some sort of conspiracy between character and spectator is implied (Belle Toujours, 2006).

In Aniki Bobó, the trope of the doll in the window is a figuration of the narrative (an emblem of childhood, innocence and magic), but, as we have seen, it also 
belongs to the domain of the figural, of the artistic discourse independent of a specific narrative and providing a clue to the entire work, as described by D. N. Rodowick in his Reading the Figural (2001). There are a few other pieces in the filmography of Oliveira where the doll as object has a figurative and figural role. Besides A Talking Picture, where it is both an emblem of the relationships between West and East and a site of historical time, in The Letter (A carta, 1999, an adaptation of the French novel by Madame de La Fayette, The Princess of Clèves, 1678, set in the present days' Portugal) it appears as a metaphor of the heroine (passive and helpless, stuck in the position of a child who promised her mother not to marry the man she loves). [Fig. 3.] It also evokes the doll in the window effect, the discourse on the (female) image as object of (male) spectatorial desire (her admirer is repeteadly standing in front of her house, staring at her window). Most intriguingly, this admirer, the Portuguese pop star Pedro Abrunhosa playing himself, never removes his dark sunglases, which makes his gaze unlocalizable. His enigmatic star-image reveals him too as an object of the female (and spectatorial) desire, an icon.

The trope of the doll in the window launched in Aniki Bobó can be regarded as a signature of Oliveira's visual aesthetics, sublimated in the very recurrent image of the (inexpressive, passive) woman in the window, exposed to a gaze that doubles that of the spectator. In most cases the woman in the window remains a distant image, the object of a distant longing of the male protagonist. This is also true for the "tetralogy of frustrated loves" - the courtly, purely platonic love for a (dead, rejected, idealized or mystified) person turns characters into carefully framed images, composed as paintings and often reflected in mirrors. The discourses on the woman as doll and woman as work of art overlap in painterly compositions.

The magic, the desire, the uncanny, the frustration and rejection they cause also make the toy/doll and the work of art comparable, as in Rilke's words quoted by Agamben: "it [the doll] makes us almost indignant at its tremendous and crass forgetfulness; that hatred that, unconscious, has always constituted a part of our relation to it breaks forth, the doll lies before us unmasked like the horrible strange body on which we have dissipated our purest warmth; like the drowned corpse painted on the surface that allowed itself to be lifted up and borne along by the floods of our tenderness, until we would dry up again, abandoning it in some hedge (Agamben 1993b, 57).

The animism, fetishism and belief in magic of children in Aniki Bobó becomes a recurrent topic in Oliveira's films as an infantile wish or belief in the living doll. As Mathias Lavin has already pointed out $(2014,130)$, both the Eccentricities of a 
Blonde Girl (Singularidades de uma Rapariga Loura, 2009) and The Strange Case of Angelica display the scene from Hoffmann's The Sand Man, where the young man falls in love with a beautiful automaton. This short story is analysed by Freud as an example of the uncanny experience consisting of "doubts whether an apparently animate being is really alive; or conversely, whether a lifeless object might not be in fact animate" (Freud 2003, 5), as it is the case of the impression made by wax-work figures, artificial dolls and automatons. But even beyond that, this trope becomes the figure of the uncanny effect of still images (paintings and photographs) animated by cinematic movement and of the opposite, of moving images turning still, transforming into tableaux vivants, visual objects, thus fulfilling the desire of a fetishist spectator.

\section{The Beautiful Automaton}

As Agamben has shown, the doll is, on the one hand, "infinitely lesser than an object, because it is distant and beyond our grasp," but "it is on the other hand infinitely more, because it is the inexhaustible object of our desire and our fantasies:" "in it [the doll] we would mix, as in a test tube, whatever unknowable things happened to us, which we would see boil up and turn colors there” (1993b, 58). In Oliveira's cinema the recurrent voyeuristic scene in which a man is contemplating a woman in the window (as already remarked by other critics, Fausto Cruchinho, 2010 or Lavin, 2014, for example) recalls children's fetishistic attraction to dolls. But beyond the fetishistic content of the male gaze that transforms the female body into "an unattainable object that satisfies a human need precisely through its being unattainable" (Agamben 1993b, 33), the doll and dollness becomes central in the Oliveirian discourse on cinematic ontology, film and modernity, movement and stillness and the cinematic image as ultimate fetish.

Baudelaire in his The Painter of Modern Life (1862) already defines modernity as "the ephemeral, the fugitive, the contingent, the half of art whose other half is the eternal and the immutable" $(1964,13)$. Philosopher Stanley Cavell, on his turn, identifies in Baudelaire's compelling presentation of aspects of modernity the myths of film, the modern medium being the only capable to satisfy "the specific simultaneity of presence and absence" of stability and futility, stillness and movement (1979, 42).

As I have already argued elsewhere (Király 2013), Oliveira, bored with the $20^{\text {th }}$ century, instead of adopting a modernist style after his return to filmmaking in the late 60s, has rather turned back to the original definition of Baudelaire by 
re-enacting the myth of modernity on film and by film, staging its paradoxical position between the stability and stillness of plastic artworks - paintings and statues - and the futility represented by the moving image. Playing an organic part of his life (itself characterized by the duality of inactivity and hyper-creativity, an active sportsman's life and contemplative lifestyle in his vineyard, followed by his spectacular return to filmmaking), his cinema is constantly revealing a fascination for both technical innovation and aesthetic tradition, the machine and the statue or painting, respectively. This duality is plastically represented in his The Cannibals (Os Canibais, 1988), a sinister opera-film displaying the uncanny effect generated by the tropes of the living dead and the automaton: the mysterious count, whom the female protagonist falls in love with, turns out to be half human, half machine, with prosthetic limbs annexed to his body. When he removes these limbs, his body is turned into a torso, reminding of antic statues: it reveals stillness, eternal beauty, movement and technology in the same human body, a complex figure of the myth of modernity. [Fig. 4.]

The same two-facedness of modernity is concentrated in the trope of the doll, or the woman who acts, moves like an automaton. Echoing Degas's painting Portrait of Michel-Levy in his studio (1879), in which the doll, the artistic prop is responsible for the uncanny effect (at first we think it is a woman, an artist's model, just to realize, from the clumsy pose, that it is an object), this motif has become in Oliveira's cinema a figuration of woman as a spectacle. Starting from Aniki Bobó, this immobile object of contemplation keeps coming back in a series of films where the woman is framed as the still object of contemplation: in Doomed Love, Francisca, The Letter, Eccentricities of a Blonde Haired Girl, or The Strange Case of Angelica. The prototype of the silent, numb female body exposed to contemplation in the window can be found in Doomed Love, where the lovers, Teresa and Simão see each other through the opposite windows of their paternal houses. They will meet only once, in a dark garden, which makes their relationship seem fantasmatic, and melodramatic circumstances transform Teresa into a passive marionette of destiny. We can say, by referring to Susan Sontag's essay The Illness as Metaphor (1988), that her sickness appears rather as a metaphor of the death drive that Laura Mulvey identifies in melodramas and which is manifested in a tendency of film action and movement to slide into non-action, stillness and ultimately death (Mulvey 2006, 67-81). The same applies to Francisca, who consents to running away with her admirer, and is taken to his house and kept there as a beautiful captive, regressing slowly into silence and stillness, to a state of living dead - as suggested by the compositions 
and light effects that show her as a lifeless doll. This trope is also emphasized by her monotonous way of speaking, symptomatic of her melancholy. In a similar vein, the female protagonist of The Letter is like a puppet devoid of own will, all her decisions being animated by the wish of her dead mother not to marry the man she loves. Thus she becomes a beautiful automaton in the window, admired from distance, just like the girl from The Eccentricities of a Blonde Haired Girl. This film is visually dominated by idealizing frames, portraits of the worshipped, mostly silent woman, and ends abruptly after showing the image of the young woman falling apart like a marionette (as Mathias Lavin also points out, 2014, 130) when her husband realizes that she is a kleptomaniac. While letting spectators fall in the abyss of the closing black screen and their unfulfilled expectations - nourished by memories of Hitchcock's Marnie (1964) or Bresson's A Gentle Woman (Une Femme Douce, 1969) -, Oliveira's artistic choice is that of a detached contemplation that is never disturbed by the obsession of solving the mystery of the woman. The male gaze, transforming her into a doll, worships her only as long as she is perfect: at the first sign of eccentricity she ends up rejected, like a doll abandoned by children.

The same reference to the infantile aspects of fetishism prevails in Abrahams's Valley, completed with the magic and the uncanny associated with the image of the female figure in the window. In this adaptation of Agustina Bessa-Luís's homonymous novel, Ema, the main character is a disturbing presence: whenever she appears in the window, car accidents happen in front of their house. Her beauty has an element of sinister linked by Lord Byron with "the doomed and the damned" (Wilson 2007, 96, 302). But most intriguingly, she has a limp, which makes her movement uncannily mechanic, automaton-like. Ema's oscillation between the traditional role of housewife staying at home and that of the independent, modern woman crossing her boundaries is doubled by still images, tableaux vivants getting on movement, and freeze-action images. She is constantly posing, looking into mirrors that become a narcissistic source of love. Pose as pause is, according Laura Mulvey, a tool of delaying cinema, resisting narrative linearity, addressing a fetishist spectator "more fascinated by image than plot" $(2006,164)$. As I have already argued in an essay on the role of stillness in Oliveira's cinema, Ema is "half doll, half idol," a female dandy, presenting herself as work of art and constantly turning herself into an image (Király 2014, 9). This "imageness" and "dollness" makes her comparable to fashion models, whose facial inexpressivity is due, according to Giorgio Agamben, to "the awareness of being exposed to the gaze." As he argues, "it is this brazen-faced indifference that fashion models, porn 
stars, and others whose profession it is to show must learn to acquire: they show nothing but the showing itself (that is, one's own absolute mediality). In this way, the face is loaded until it bursts with exhibition-value. Yet, precisely through this nullification of expressivity, eroticism penetrates where it could have no place: the human face, which does not know nudity, for it is always already bare. Shown as a pure means beyond any concrete expressivity, it becomes available for a new use, a new form of erotic communication" $(2007,90)$.

The uncanny effect of the expressionless doll-face is often emphasized by a gaze that is looking back at the spectator, transforming the motionless body in the image into a disquieting presence. As Manet's Olympia (1863) testifies, this is, beyond the presentation of the female body as an object of the male gaze, a self-reflexive thematization of the female body exposed to the gaze. This trope finds a complex autobiographical, media-theoretical and artistic-cultural representation in The Strange Case of Angelica, a film rich, as the title suggests, in uncanny effects that transform the beautiful automaton into a transitional object between life and death.

\section{The Doll as Transitional Object}

Dramatic circumstances like the death of a young female cousin, that of one of his grandsons and his advanced age have continuously nurtured Oliveira's preoccupation with death, figurated and sublimated over and over in his films about strange cases of deadly, obsessive and pathological passions. Morbidity is a constant poetical source for Oliveira and the death scene a paradoxical figuration of life, in accordance with Foucault's observation: "the morbid authorizes a subtle perception of the way in which life finds in death its most differentiated figure. The morbid is the rarefied form of life, exhausted, working itself into the void of death." Foucault also defines death as "the lyrical core of man: his invisible truth, his visible secret" $(2003,245)$.

One of the recurrent scenes of Oliveira's films - as it can be seen in Doomed Love, Benilde or the Virgin Mother, Francisca, Magic Mirror (Espelho Mágico, 2005), The Strange Case of Angelica, to name just a few -, that of the death of a young woman (coined as the most poetical image ever by Edgar Allen Poe), strikes us as both painterly due to its composition and photographic in capturing the moment and framing the perfect stillness of doll-like bodies. [Fig. 5.] These two qualities are reconciled in the intermedial figure of the tableau vivant, often present in Oliveira's movies. The Strange Case of Angelica is further illuminating the inherent intermediality of the cinematic image, indebted 
both to the painterly and the photographic tradition. The film is overtly selfreflexive and metaleptic, bearing numerous autobiographical details, not to mention that he casts in the role of the main protagonist his grandson, Ricardo Trêpa. The young photographer played by him is hired to take photos of a dead young woman, Angelica, a mission that turns to be fatal for him. In the scene of the photo session we are witnessing a reframing of the image of the beautiful dead girl (who seems alive and even smiling in her death) that results in an intermedial flickering between film, painting and photograph. The film is making the frames, boundaries and crossings visible, thus becoming a whole concentrated history of cinematic intermediality from painterly composition through photographic freeze-frame to the movement dissolving the stillness. This oscillation presents cinema again as a medium indebted both to modernity, characterized by Baudelaire as both contingent and stable, and to cinematic modernism that pushed the experimentation with aesthetic possibilities of the stillness-movement duality to the extreme. The painterly composition of the motionless body of the girl, reminding of Renoir's painting of Madame Monet $(1872)^{2}$ is being reframed by the camera of the photographer, then blurred, in a reference to the impressionist painting and revealing the materiality of the image. [Figs. 6-7.] But the strange case of Angelica starts when, through the lens of the camera, the girl comes back to life, in a media theoretical version of the fairy tale of Sleeping Beauty, and evoking the uncanny effect of the beautiful automaton. Thus, beyond this short genealogy of intermedial relationships including socio-cultural background, such as the practice of taking photos of dead people, or the retaining of the moment, of the atmosphere in impressionist paintings - we are witnessing here a figuration of the cinematic technology, presented as a miracle that makes the still image move. Following this scene, the photographer becomes obsessed with this girl who is visiting him every night and takes him to fly, in a setting reminding of the films by Meliès (using the technique of superimposition), until one morning he is found dead in the boarding house where he lives. This story, that can be well interpreted as an allegory of the fatal attraction between life and death, stillness and movement, as well as film and photography, ends by showing the photographic image as the ultimate common denominator of the two technologies. Theorized by Bazin (2005), Barthes (1985), or more recently by Raymond Bellour (2002a, 2002b) and Laura Mulvey (2006), the photographic (and still) image in film addresses

2 This reference might not be a coincidence as the painting is in the collection of the Gulbenkian Modern Art Museum in Lisbon, and Oliveira was most probably familiar with it. 
a pensive and fetishist spectator. Moreover, according to Bellour (2002a), stillness in cinema traditionally serves to represent the non-representable, like birth, death, or miracles of Christianity such as resurrection, immaculate conception and apparitions, topics systematically exploited by Oliveira since the beginning of the 1970s.

Blurring the borders of media and those between movement and stillness, life and death refers to the ontology of photography, and by opposing stillness in the image and stillness of the image, it reveals cinematic stillness as a trompe l'oeil. In the films of Oliveira the scenes of dying are very long shots meant to grab the moment of passage from movement to stillness, from the cinematic to the photographic. The same intention to reveal the discreet line between painting, photograph and film can be found in Benilde, or the Virgin Mother, where the photograph of the protagonist's mother, framed as a painting and repeatedly intercut with the ongoing scene, "comes to life" in three steps: first her expression changes, then slightly turns towards us, and finally we are witnessing the scene through her point of view, in another emergence of the uncanny. [Figs. 8-9.] What we have here, again, is a concentrated genealogy and a revelation of the technical mechanisms of the medium, of the movement achieved as a succession of individual images. An exaggerated slowing down and repeated reframing turns this scene into a real cinephile delicacy. As Belén Vidal argues, the emphasis on framing as artifice and "instances of temporal and spatial manipulation" such as fixed framings, long takes, slow motion, zooms or superimpositions "strain the narrative as a whole, drawing our attention to the visual textures of the film. This 'overwriting' of the shot throws into relief tensions between discursive and figural dimensions of film" (Vidal 2012, 111).

In the light of the discussion above I contend that Oliveira, through the trope of the doll and automatons not only thematizes intermedial transitions as figurations of movement and stillness, but, as already hinted at earlier, conceives film itself as a transitional object between the familiar and the unfamiliar. The psychoanalytical concept of transitional object was initially used in the description of a developmental stage of infants that has been later extended to the cultural experience of adults. According to its original definition, for a baby, a transitional object such as a blanket, a pacifier, a cuddly toy, serves to relate between outer and inner reality, facilitating the child's acceptance of the new. In Winnicott's view, "no human being is free from the strain of relating outer and inner reality," and transitional objects and transitional phenomena help us negotiate that relationship (quoted by Kuhn, 2005, 401). Agamben links the 
concept of fetish with that of the transitional object that does not belong to the internal and subjective nor to the external, but to "the area of illusion," the location of culture and play, a "third area" (1993b, 59). Annette Kuhn, in her Thresholds: Film as Film and the Aesthetic Experience (2005) considers transitional processes in adult life in terms of an aesthetic moment (a term borrowed from Bernard Berenson via Marion Milner) defined as an occasion when time becomes space (that is, concretizes in an object) for the subject. We are stopped, held in reverie, to be released eventually back into time proper (Kuhn 2005, 401).

In the aesthetic moment, the subject then becomes part of that reality, and that reality becomes part of the subject, which reminds us of the phenomenological description of the film experience by Merleau-Ponty saying: "well, the movies are particularly suited to make manifest the union of mind and body, mind and world, and the expression of one in the other" (quoted in Kuhn 2005, 405). Annette Kuhn in her essay takes this idea even further arguing that this experience is due to a particular configuration of space within and outside the edges of the film image, the film frame: "through its organization within the frame of space, time, stillness and motion, film is capable, I would suggest, of replaying or re-evoking certain states of being which are commonly experienced as inner. This, I would argue, is the site of the activity of transitional processes" (Kuhn 2005, 403). This is very close to Laura Mulvey's approach to cinematic stillness and film frame modelling "the longstanding reluctance of the human mind to confront death" (Mulvey 2006, 43). I argue that what makes Oliveira's case special, beyond the aesthetic moment achieved through a constant reframing that reconciles images of life with those of stillness and death, is his obstinate clinging to cinema as a unique language - a transitional object - which translates the experience of the passage between life and death. Films become the fetishistic object capable of making this transition smooth, just as the dead woman is helping the photographer's passage in The Strange Case of Angelica. In this film the obsession for the beautiful automaton and for photography overlap: the strangeness of Oliveira's case consists of an exaggerated cinephilia, an obsession with the aesthetic moment that, according to Kuhn, "is characterized by a feeling of being, or becoming, at one with a work of art; and this entails a sensation of crossing over a boundary and entering into another kind of reality - and then returning 'home,' renewed" $(2005,404)$.

It might not be exaggerated to say that Oliveira is performing this experience over and over, with the euphoria of the artist directly involved with the moving image, in a game with the frames and intermedial possibilities of the medium, somehow evoking the experiments of the avant-garde artists of initial times. 
Because he is not only an eccentric, a cinephile par excellence, but also a cinéfils, to use Serge Daney's playful term, the son of cinema. His stories might appear clumsy, outmoded, uncanny or too simple, but they always serve as background for the figuration through the still, painterly or photographic image. As Ágnes Pethő has put it: "still image appears to be 'folded' over movement, while the spectator is invited not to a narrative decoding but to a kind of postcinematic contemplation over individual frames and scenes" $(2011,6)$. These frames, marking intermedial boundaries are only partly figurations of the story: as I was arguing above, Oliveira manages to isolate and sublimate the still image (of a woman represented as a doll, mannequin or automaton) as a figure of the dynamics of life and death.

\section{References}

Agamben, Giorgio. 1993a. History and Infancy. London, New York: Verso.

Agamben, Giorgio. 1993b. Stanzas. Word and Phantasm in Western Culture.

Minneapolis: University of Minnesota Press.

Agamben, Giorgio. 1999. The Man without Content. Stanford: Stanford University

Press.

Agamben, Giorgio. 2007. Profanations. New York: Zone Books.

Araújo, Nelson, ed. 2014. Manoel de Oliveira. Analíse estética de uma matriz cinematográfica [Manoel de Oliveira. Aesthetic Analysis of a Cinematographic Matrix]. Lisboa: Edições 70.

Araújo, Nelson. 2014. Entrevista com Manoel de Oliveira [Interview with Manoel de Oliveira]. In Manoel de Oliveira. Analíse estética de uma matriz cinematográfica [Manoel de Oliveira. Aesthetic Analysis of a Cinematographic Matrix],135-146. Lisboa: Edições 70.

Baecque, Antoine and Jacques Parsi. 1999. Conversas com Manoel de Oliveira [Conversations with Manoel de Oliveira]. Porto: Campos das Letras.

Baudelaire, Charles. 1964 [1863]. The Painter of Modern Life. In Baudelaire: The Painter of Modern Life and Other Essays, 1-41. London: Phaidon Press.

Barthes, Roland. 1985. The Third Meaning: Research Notes on Several Eisenstein Stills. In The Responsibility of Forms: Critical Essays on Music, Art, and Representation, 41-62. Berkeley: University of California Press.

Bazin, André. 2005. The Ontology of the Photographic Image. In What is Cinema? Vol. I, 9-16. Berkeley [etc.]: University of California Press. 
Bellour, Raymond. 2002a. Le spectateur pensif. In L'Entre-Images. Photo. Cinéma. Vidéo. Les Essais [Between-the-Images. Photo. Cinema. Video], 75-80. Paris: Éditions de la Différence.

Bellour, Raymond. 2002b. L'Interruption, L'instant. In L'Entre-Images. Photo. Cinéma. Vidéo. Les Essais [Between-the-Images. Photo. Cinema. Video], 109134. Paris: Éditions de la Différence.

Berger, John. 1972. Ways of Seeing. Gloucester: Peter Smith Publisher.

Bonitzer, Pascal. 1985. Décadrages - Peinture et Cinéma. Paris: Cahiers de Cinéma, Éditions de l’Étoile.

Bordwell, David. 2013. Looking at the Fourth Wall.

http://www.davidbordwell.net/blog/Category/directors-oliveira/. Last accessed 28. 08. 2018.

Cavell, Stanley. 1979. Baudelaire and the Myths of Film. In Reflections on the Ontology of Film, 41-60. Cambridge, MA and London: Harvard University Press.

Costa Andrade, Sérgio. 2008. Ao correr do tempo. Duas decadas com Manoel de Oliveira [Over time. Two Decades with Manoel de Oliveira]. Lisboa: Portugália Editora.

Costa, João Bénard. 1981. Diálogo com Manoel de Oliveira. In Manoel de Oliveira, 31-46. Lisboa: Cinemateca Portuguesa.

Cruchinho, F. 2010. A Mulher na Montra e o Homem olhando para ela [The Woman in the Display Window and the Man Looking at Her]. In Manoel de Oliveira: uma presença [Manoel de Oliveira: a Presence], 87-96. São Paulo: Perspectiva.

Daney, Serge. 2001. Notes sur les films de Manoel de Oliveira. In La Maison Cinéma et le monde I: Le temps des Cahiers [The Cinema House and the World I: The Time of the Cahiers], 225-227. Paris: P.O.L.

Foucault, Michel. 2003. The Birth of the Clinic. An Archaeology of Clinical Perception. New York, London: Routledge.

Freud, Sigmund. 2003. The Uncanny. London: Penguin Classics.

Király, Hajnal. 2013. Stillness, Fashion and the Myth of Modernity in the Cinema of Manoel de Oliveira. In Atas do II Encontro Anual da AIM, eds. Tiago Baptista and Adriana Martins, 297-308. Lisboa: AIM.

Király, Hajnal. 2014. Frames, Windows and Mirrors. Sensing Still Bodies in Films by Manoel de Oliveira. Acta Universitatis Transilvaniae, Film and Media Studies no. 8: 7-20. 
Kuhn, Annette. 2005. Thresholds: Film as Film and the Aesthetic Experience. Screen vol. 46, no. 4 (winter): 401-414.

Lavin, Mathias. 2008. La Parole le lieu. Le cinema selon Manoel de Oliveira [The Word and the Place. The Cinema according to Manoel de Oliveira]. Rennes: Presses Universitaires de Rennes.

Lavin, Mathias. 2014. A palavra [The Word]. In Manoel de Oliveira. Analíse estética de uma matriz cinematográfica [Manoel de Oliveira. Aesthetic Analysis of a Cinematographic Matrix], 123-134. Lisboa: Edições 70.

Lopes, João. 1981. A Boneca na Montra [The Doll in the Display Window]. In Manoel de Oliveira, 57-59. Lisboa: Cinemateca Portuguesa.

Mulvey, Laura. 2006. Death24 x a Second. London: Reaktion Books.

Parsi, Jacques. 1981. A trilogia dos amores frustrados [The Trilogy of Frustrated Loves]. In Manoel de Oliveira, 71-78. Lisbon: Cinemateca Portuguesa.

Pethő, Ágnes. 2011. Cinema and Intermediality: the Passion for the In-Between. Newcastle upon Tyne: Cambridge Scholars Publishing.

Rodowick, D. N. 2001. Reading the Figural or, Philosophy after the New Media (Post-Contemporary Interventions). Durham: Duke University Press.

Rosenbaum, Jonathan. 1995. Placing Movies: The Practice of Film Criticism. Berkeley: University of California Press.

Sontag, Susan. 1988. The Illness as Metaphor. New York: Farrar, Straus and Giroux.

Vidal, Belén. 2012. Figuring the Past. Period Film and the Mannerist Aesthetic. Amsterdam: Amsterdam University Press.

Wilson, Elizabeth. 2007. A Note on Glamour. Fashion Theory vol. 11, no. 1: 95108. 


\section{List of Figures}

Figures 1-2. The doll in the window in Aniki Bobó (1942).
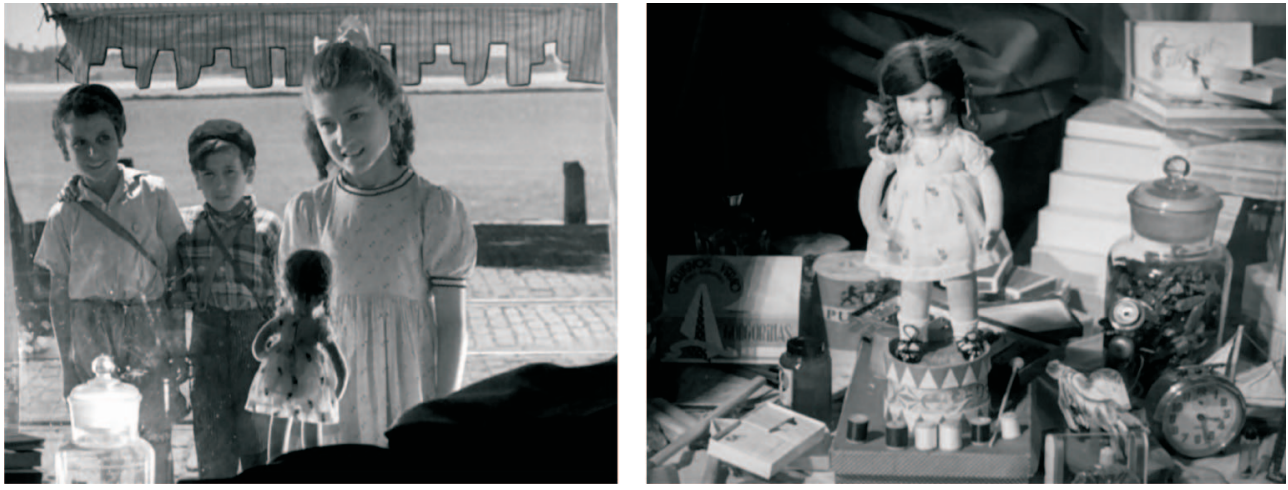

Figure 3. The doll as metaphor in The Letter (1999). Figure 4. Merging the tropes of the living dead and the automaton in The Cannibals (1988).
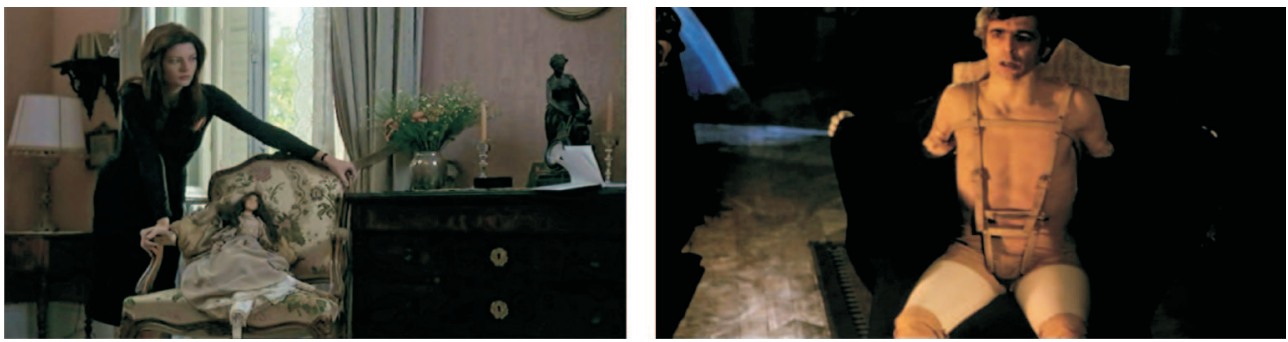

Figure 5. Framing the scene of dying of the female protagonist in the Magic Mirror (2005).

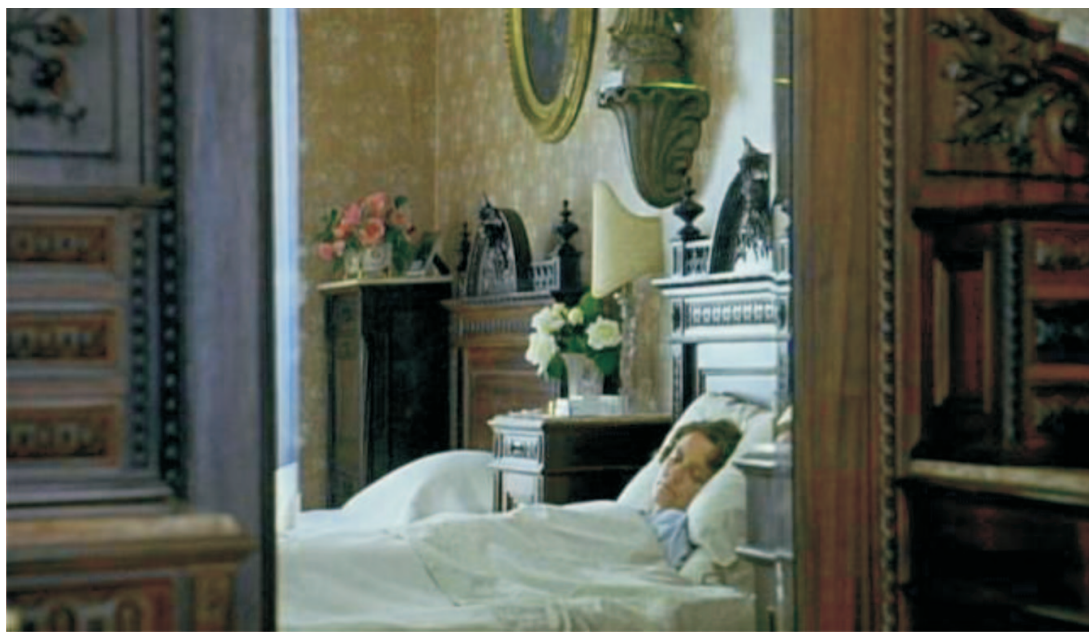


Figures 6-7. The painterly image of the dead woman in The Strange Case of Angelica (2010), echoing Renoir's Madame Monet Reading (1872).
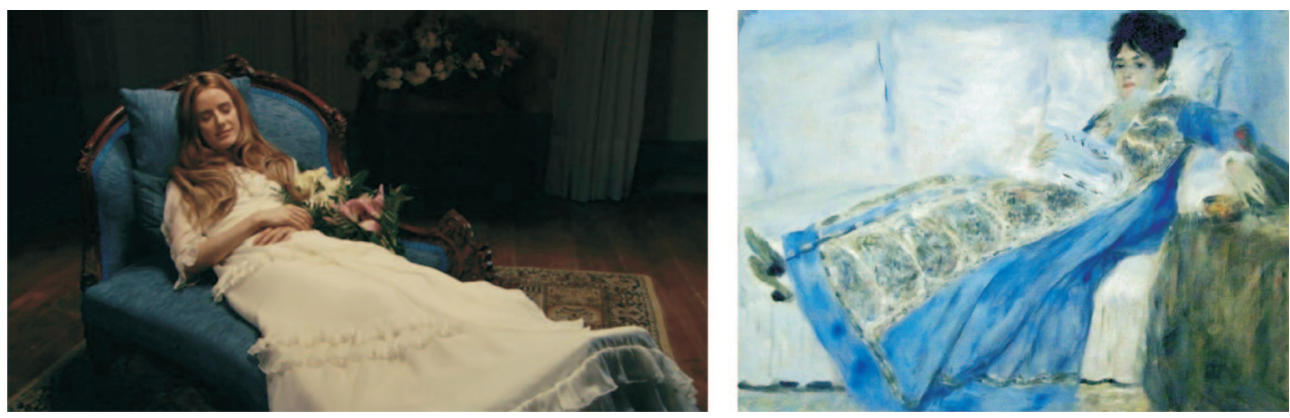

Figures 8-9. The uncanny effect of the "living photograph" in Benilde, or the Virgin Mother (1975).
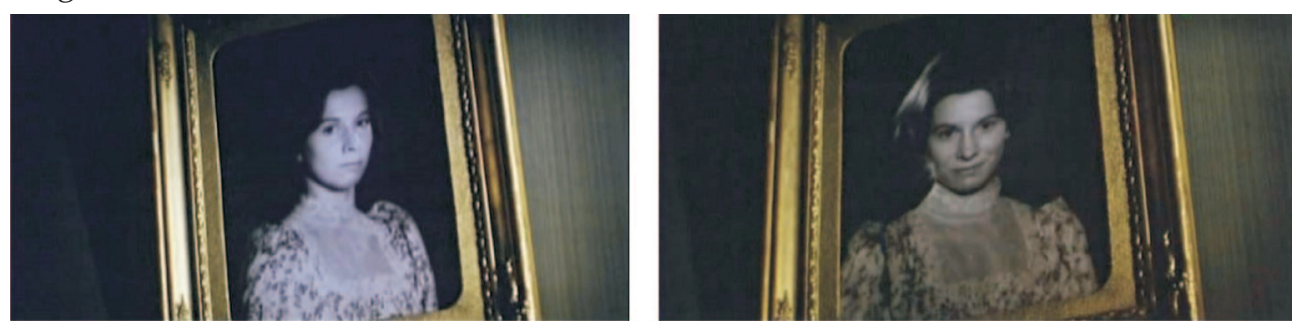